\title{
Evaluating the Profitability of Foliar Fungicide Programs in Mid-Atlantic Soft-Red Winter Wheat Production
}

Phillip N. Sylvester, ${ }^{\dagger}$ Cooperative Extension Service, University of Delaware, Newark 19716; Felipe Dalla Lana, Department of Plant Pathology, The Ohio State University, Ohio Agricultural Research and Development Center, Wooster 44691; Hillary L. Mehl, Department of Plant Pathology, Physiology, and Weed Science, Virginia Tech, Tidewater Agricultural Research and Extension Center, Suffolk 23437; Alyssa A. Collins, Department of Plant Pathology and Environmental Microbiology, The Pennsylvania State University, Southeast Agricultural Research \& Extension Center, Manheim 17545; Pierce A. Paul, Department of Plant Pathology, The Ohio State University, Ohio Agricultural Research and Development Center; and Nathan M. Kleczewski, Department of Plant and Soil Sciences, University of Delaware

\begin{abstract}
In mid-Atlantic soft-red winter wheat (SRWW) production, the standard timing for a fungicide application is between flag leaf emergence (Feekes growth stage [FGS] 8) and heading (FGS 10.5). However, two-pass and anthesis (FGS 10.5.1) applications are becoming common, although these programs have not been thoroughly evaluated for disease control, yield, and profitability. Experiments were conducted in the mid-Atlantic in 2015 and 2016 to evaluate fungicide programs with applications at FGS 8, FGS 10.5.1, and two-pass programs with an early application at green-up (FGS 5) followed by (FB) applications at either FGS 8 or

FGS 10.5.1. Fungicide programs that included an application at FGS 10.5.1 resulted in the highest probability of no disease on the flag leaf $(0.29$ to 0.40$)$. The estimated mean yield increases $(\bar{D})$ relative to the nontreated check ranged from 253.65 to $634.16 \mathrm{~kg} \mathrm{ha}^{-1}$. Using a grain price of $\$ 0.18 \mathrm{~kg}^{-1}\left(\$ 5\right.$ bushel $\left.^{-1}\right)$, probabilities were similar between applications at FGS $8(0.49$ to 0.56$)$ and FGS 10.5.1 (0.53). The probability of profitability ranged from 0.48 to 0.57 for FGS 5 FB FGS 8 applications and 0.52 to 0.59 for FGS 5 FB FGS 10.5.1 applications, indicating limited benefit to two-pass programs.
\end{abstract}

In the mid-Atlantic states of Delaware, Maryland, Pennsylvania, and Virginia, soft-red winter wheat (Triticum aestivum L.) (SRWW) is harvested from over 263,000 ha, with an average yield of $4,237 \mathrm{~kg}$ $\mathrm{ha}^{-1}$ and an annual value of over $\$ 232$ million (USDA-NASS 2016, 2017a). SRWW is an important part of the agricultural economy in the mid-Atlantic, supplying feed for the poultry industry on the Delmarva Peninsula and grain for the large flour mill industry in Pennsylvania, Maryland, and Virginia (USDA-NASS 2017b). Wheat production in this area is negatively affected by several fungal diseases affecting the foliage and spike (Kleczewski 2014c, 2017a; Weisz et al. 2011). These diseases include the residue-borne leaf blotch complex (LBC) of Stagonospora nodorum blotch (Parastagonospora nodorum (Berk.) Quaedvl., Verkley \& Crous), Septoria tritici blotch (Zymoseptoria tritici (Roberge ex Desm.) Quaedvl. \& Crous), and tan spot (Pyrenophora tritici-repentis (Died.) Drechsler). Other foliar diseases encountered less frequently in the region include powdery mildew (Blumeria graminis (DC.) Speer.), leaf rust (Puccinia triticina Erikss.), and stripe rust (P. striiformis Westend.) (Bowen et al. 1991; Cowger et al. 2016a; Green et al. 2014). Last, Fusarium head blight (Fusarium graminearum Schwabe) (FHB) and Stagonospora glume blotch (Parastagonospora nodorum), diseases that affect the spikes and glumes (Milus and Chalkley 1997; Salgado et al. 2015), are also part of the disease complex in the region. Collectively, these diseases have the potential to significantly reduce grain yield and test weight in the mid-Atlantic in years that are favorable for disease development (Kleczewski 2017a,b; Phipps et al. 2012; Sylvester and Kleczewski 2018).

${ }^{\dagger}$ Corresponding author: P. N. Sylvester; E-mail: phillip@udel.edu

Funding: Funding for this research was provided by the Maryland Grain Producers Utilization Board Grant Number 2016361.

*The $\boldsymbol{e}$-Xtra logo stands for "electronic extra" and indicates that three supplementary figures are published online.

Accepted for publication 2 March 2018.

(c) 2018 The American Phytopathological Society
Infection of the flag leaf and spikes has the greatest impact on yield because the majority of carbohydrates necessary for grain fill are produced by the flag leaf (45\%), flag leaf sheath $(25 \%)$, and spike $(25 \%)$ (Lupton 1972), whereas only 5\% is derived from other portions of the plant canopy. Fungicides are used as a tool, along with variety selection and cultural practices, to minimize yield losses from fungal diseases by protecting these tissues. However, there is an existing knowledge gap in fully explaining the yield loss-disease relationship for many foliar diseases such as LBC and economic thresholds (Ficke et al. 2018). Therefore, many growers have turned to prophylactic applications based on crop developmental stage (Chen et al. 2015). There are several additional reasons for utilizing such a program, including ease of scheduling, increased availability and reduced cost of fungicides, increased focus on grain quality, and the perceived notion of protecting or increasing the return on an investment.

Historically, fungicide applications in the region have been made between flag leaf emergence (Feekes growth stage [FGS] 8) and heading (FGS 10.5) (Large 1954). However, there has been a shift away from FGS 8 fungicide programs to applications within 5 days of the start of flowering (FGS 10.5.1). This timing is the most effective for managing FHB (D'Angelo et al. 2014) and recent studies from the region indicate that it may be as effective as FGS 8 applications for managing common foliar diseases (Sylvester and Kleczewski 2018). Another trend is the inclusion of a reduced-rate fungicide with the application of nitrogen prior to jointing (FGS 6) to minimize earlyseason disease development without the added cost of a separate application (Wegulo et al. 2012; Willyerd et al. 2015). A recent study examining fungicide programs for impact on foliar disease and yield in Delaware and Maryland indicates that programs using the two-pass approach may result in a small (198 and $192 \mathrm{~kg} \mathrm{ha}^{-1}$ ), though significant, yield increase when compared with single applications at FGS 8 or FGS 10.5.1 (Sylvester and Kleczewski 2018). However, such a small increase in yield may not be sufficient to offset application costs, which are generally influenced by the number of applications and product selection.

Growers have access to a multitude of fungicide products in small grains and the cost of these fungicides varies greatly. For example, in 2015 and 2016, we requested current prices for five commonly used fungicides from regional chemical suppliers in the mid-Atlantic. Using these data, we calculated that the amount of yield needed to offset 
the price differential relative to a nontreated control (assuming an average ground application cost of $\$ 19.24 \mathrm{ha}^{-1}$ and a grain price of $\$ 0.18 \mathrm{~kg}^{-1}$ ) would range from $155 \mathrm{~kg} \mathrm{ha}^{-1}$ with the low-cost product to more than double that $\left(350 \mathrm{~kg} \mathrm{ha}^{-1}\right)$ with the more expensive product. Thus, a low-cost, less-efficacious product could potentially result in similar or increased potential net profitability to a grower, depending on the situation. Similarly, multiple-pass programs include an additional chemical cost, despite reducing the overall application cost by including a fungicide with an early-season nitrogen application.

Fungicide economics have been previously assessed in other wheat classes and growing regions of the United States. In northeast Texas SRWW, Lopez et al. (2015) reported tebuconazole sprayed at FGS 10 produced notable returns $\left(\$ 107.70 \mathrm{ha}^{-1}\right)$ in one year and net loss in the other $\left(-\$ 3.53 \mathrm{ha}^{-1}\right)$. In Nebraska hard red winter wheat, Wegulo et al. (2011) reported that profits were greatest when environmental conditions favor moderate to severe disease development, though low wheat prices may still result in net losses by using a fungicide. Thompson et al. (2014) reported that hard red winter wheat varietal selection in Oklahoma may also influence profitability when using fungicides, especially on susceptible varieties in high-disease environments. In the Great Lakes region of the United States, Willyerd et al. (2015) tested tebuconazole + prothioconazole (Prosaro) and pyraclostrobin (Headline) at FGS 5, FGS 8, or FGS 10 as well as two-pass programs for control of LBC in SRWW. Using a multivariate random-effects meta-analysis, the authors generated data as to the likelihood that a given fungicide program would result in a yield gain large enough to offset application costs across three levels of grain price scenarios. Their work indicated that fungicides applied at FGS 8 or FGS 10 provided roughly the same chance of resulting in a positive yield response compared with two-pass systems. However, results were limited to two fungicide products, did not utilize the commonly used FGS 10.5.1 application program, and did not represent the mid-Atlantic region, which is characterized by moderate temperatures, high humidity, and diverse cropping systems. Weisz et al. (2011) analyzed 42 fungicide trials conducted from 1994 to 2010 in the mid-Atlantic states of Virginia and North Carolina, and reported a low probability $(\leq 0.50)$ of profitability in nodisease environments, compared with a greater probability $(\geq 0.50)$ when disease was recorded. However, the authors state that the wheat cultivars used in fungicide trials are often susceptible to at least one foliar disease, which can often increase the yield response to fungicides. Our work contributes to Weisz et al. (2011) by conducting a planned experiment, across four mid-Atlantic states, using the same fungicide programs at each site on a commercially available, moderately resistant wheat variety, in order to gain a better understanding of the impact of fungicide programs on grain yield and profitability under typical field conditions which a grower might experience. By assessing fungicide programs in this way, we can estimate the average likelihood that a fungicide application will return a profit to a grower across the region.

Growers are often interested in the potential yield response from and economics of a fungicide application, which is essentially asking about the mean yield difference compared with a nontreated check (estimated effect size) and whether such a difference is great enough to offset application cost. Therefore, the goal of this research was to assess the profitability of commonly used fungicide programs in SRWW in the mid-Atlantic region of the United States. To accomplish this goal, we assessed the effects of multiple fungicides and application timings, representing commonly used fungicide programs in the mid-Atlantic, on grain yield and foliar fungal disease suppression through a set of replicated field studies conducted in Delaware, Maryland, Virginia, and Pennsylvania in 2015 and 2016. These data were then used to assess the likelihood of these programs producing a yield response sufficient to pay for the application cost. This information could lay the groundwork for creating a tool to assist growers in the fungicide decision-making process for managing foliar diseases in mid-Atlantic winter wheat.

\section{Materials and Methods}

Experimental design and plot establishment. Ten trials were conducted over 2 years, four in 2015 and six in 2016, in the midAtlantic states of Delaware, Maryland, Pennsylvania, and Virginia (Table 1). The experimental design was a randomized complete block with six replications, except for PA16 and VA16, that had five and four replications, respectively. SRWW variety Growmark FS815 was sown at a rate of $4.4 \times 10^{6}$ seeds ha ${ }^{-1}$ with no-till drills. FS815 was selected because it represents a commercially available, highyield-producing variety planted throughout the region (University of Delaware 2012-2014; University of Maryland 2012-2014). The variety is characterized as medium maturity, with average test weight and height and moderate resistance to foliar diseases common to the region (Kleczewski 2013, 2014b). Plot dimensions and row spacing were similar, though they varied slightly depending on field equipment (Table 1). Nontreated border rows between adjacent plots and at plot ends were used at most sites. Sites were selected to provide a range of cropping systems and environmental conditions (Table 1). Standard nutrient and pest management practices were followed for each state based on local extension suggestions (Coale 2010; Curran et al. 2016; Herbert and Flessner 2016; Maguire and Heckendorn 2015; Roth et al. 2016; Shober et al. 2017). When available, irrigation was applied as needed and amounts were recorded using a WatchDog data logging rain gauge (Spectrum Technologies, Aurora, IL) (Table 1). Temperature and rainfall data recorded by nearby weather stations were downloaded from the Delaware Environmental Observing system (Legates et al. 2005), University of Maryland System, Agricultural Experiment Station, Wye Research and Education Center in Maryland (University of Maryland 2017),

Table 1. Description of sites used to evaluate foliar fungicides programs in mid-Atlantic soft-red winter wheat production

\begin{tabular}{|c|c|c|c|c|c|c|c|c|c|}
\hline Abb. & Site & Coordinates & $\underset{\left(\text { irrig) }(\mathrm{cm})^{\mathrm{a}}\right.}{\operatorname{Rain}}$ & Soil class & $\begin{array}{l}\text { Previous } \\
\text { crop }\end{array}$ & Planting date & $\begin{array}{c}\text { Plot } \\
\text { size }(\mathbf{m})\end{array}$ & $\begin{array}{c}\text { Row } \\
\text { spacing }(\mathbf{m})\end{array}$ & Harvest date \\
\hline \multicolumn{10}{|l|}{2015} \\
\hline FT15 & Felton, DE & $39.006^{\circ} \mathrm{N}, 75.569^{\circ} \mathrm{W}$ & $29(7.2)$ & Sandy loam & Corn & 29 October 14 & $1.4 \times 7$ & 0.18 & 1 July 15 \\
\hline GT15 & Georgetown, DE & $38.637^{\circ} \mathrm{N}, 75.453^{\circ} \mathrm{W}$ & $18(5.1)$ & Loamy sand & Corn & 8 October 14 & $1.4 \times 7$ & 0.18 & 23 June 15 \\
\hline HB15 & Harbeson, DE & $38.679^{\circ} \mathrm{N}, 75.246^{\circ} \mathrm{W}$ & $15(14.4)$ & Loamy sand & Corn & 27 October 14 & $1.5 \times 7$ & 0.19 & 25 June 15 \\
\hline WY15 & Queenstown, MD & $38.916^{\circ} \mathrm{N}, 76.140^{\circ} \mathrm{W}$ & 18 & Silt loam & Corn & 20 October 14 & $1.5 \times 7$ & 0.19 & 25 June 15 \\
\hline \multicolumn{10}{|l|}{2016} \\
\hline FT16 & Felton, DE & $39.006^{\circ} \mathrm{N}, 75.569^{\circ} \mathrm{W}$ & 31 & Sandy loam & Corn & 15 October 15 & $1.4 \times 7$ & 0.18 & 30 June 16 \\
\hline GT16 & Georgetown, DE & $38.637^{\circ} \mathrm{N}, 75.453^{\circ} \mathrm{W}$ & $38(3.8)^{\mathrm{b}}$ & Loamy sand & Wheat & 9 October 15 & $1.4 \times 7$ & 0.18 & 1 July 16 \\
\hline HB 16 & Harbeson, DE & $38.679^{\circ} \mathrm{N}, 75.246^{\circ} \mathrm{W}$ & $33(3.6)$ & Loamy sand & Corn & 24 October 15 & $1.5 \times 7$ & 0.19 & 7 July 16 \\
\hline WY16 & Queenstown, MD & $38.916^{\circ} \mathrm{N}, 76.140^{\circ} \mathrm{W}$ & 32 & Silt loam & Corn & 13 October 15 & $1.5 \times 7$ & 0.19 & 27 June 16 \\
\hline PA16 & Manheim, PA & $40.118^{\circ} \mathrm{N}, 76.427^{\circ} \mathrm{W}$ & 41 & Silt loam & Soybean & 15 October 15 & $1.5 \times 6$ & 0.19 & 12/13 July 16 \\
\hline VA16 & Suffolk, VA & $36.683^{\circ} \mathrm{N}, 76.766^{\circ} \mathrm{W}$ & 35 & Loamy fine sand & Peanut & 25 November 15 & $1.2 \times 6$ & 0.17 & 20 June 16 \\
\hline
\end{tabular}

${ }^{a}$ FT15, GT15, HB15, GT16, and HB16 were the only sites with irrigation. Total irrigation (irrig) amounts follow rainfall (Rain) total in parentheses where applicable.

${ }^{\mathrm{b}}$ Estimated total irrigation due to rain gauge malfunction. 
National Climatic Data Center in Pennsylvania (NOAA 2017), and Virginia Cooperative Extension InfoNet (Virginia Tech 1997).

Fungicide programs. Thirteen fungicide programs were used, consisting of demethylation inhibitor (DMI), quinone outside inhibitor (QoI), and succinate dehydrogenase inhibitor fungicides applied either individually or sequentially at one or more of three growth stages (timings) (Table 2). The fungicides tested were propiconazole (as Tilt; Syngenta Crop Protection, Greensboro, NC), azoxystrobin + propiconazole (as Quilt Xcel; Syngenta Crop Protection), fluxapyroxad + pyraclostrobin (as Priaxor; BASF Corporation, Research Triangle Park, NC), prothioconazole + trifloxystrobin (as Stratego YLD; Bayer CropScience, Research Triangle Park, NC), and prothioconazole + tebuconazole (as Prosaro 421SC; Bayer Crop Science). These fungicides differed in initial cost and mode of action, and represented commonly used products in the region. The application timings tested included FGS 8/9 (flag leaf emergence), FGS 10.5.1 (beginning flower), and two-pass applications, with the first at FGS 5 (leaf sheaths strongly upright, commonly referred to as green-up) followed by the second at either FGS 8 or FGS 10.5.1. FGS 5 applications are marketed as preventing yield losses due to early-season disease development; however, these programs have not been thoroughly tested in the mid-Atlantic region. FGS 8 applications are aimed at protecting the flag leaf from foliar diseases but are less effective against diseases of the spike and late-season foliar diseases. FGS 10.5.1 applications are becoming more common and are the newest fungicide application timing used in the region. This timing is used primarily to manage FHB and Stagonospora glume blotch but also protects the flag leaves and spikes from other late-season diseases (Kleczewski 2014 a,c,d).

All fungicide treatments included $0.125 \%$ ( vol $/ \mathrm{vol}$ ) of a nonionic surfactant (as Induce; Helena Chemical Company, Collierville, TN). At Delaware and Maryland sites, treatments were applied using a $\mathrm{CO}_{2}$ pressurized backpack sprayer (R\&D Sprayers, Opelousas, LA) and offset handheld boom equipped with three XR8002 flat-fan nozzles (TeeJet Technologies, Wheaton, IL) spaced $50.8 \mathrm{~cm}$ apart. Treatments were made at a spray pressure of $234 \mathrm{kPa}$ to deliver spray solution at 187 liters $\mathrm{ha}^{-1}$. For the Virginia study site, treatments were applied with a tractor-mounted sprayer (LeeAgra, Lubbock, TX) using eight 8002 VS nozzles spaced $46 \mathrm{~cm}$ apart at a rate of 186 liters ha ${ }^{-1}$ and a pressure of $262 \mathrm{kPa}$. For the Pennsylvania site, treatments were applied with a tractor-mounted custom-built plot sprayer by research staff at The Pennsylvania State University. Four AITTJ6011002 TeeJet nozzles were spaced $48 \mathrm{~cm}$ apart on the boom and calibrated to apply at a rate of 187 liters ha ${ }^{-1}$ at a pressure of $276 \mathrm{kPa}$.

Data collection and analysis. Flag leaf disease assessment and yield. Total disease severity was estimated as the percent flag leaf area affected by one or more members of the leaf blotch complex (Stagonospora nodorum blotch, Septoria tritici blotch, and tan spot), leaf rust, powdery mildew, or stripe rust. In 2015, only the LBC was detected and rated on the flag leaf at all sites. In 2016, a combination of foliar diseases were detected, with LBC being the most prevalent, followed by leaf rust, powdery mildew, and stripe rust, and estimated as total disease severity on the flag leaf rather than rating each disease separately. A subsample of leaves from the nontreated control plots was occasionally collected and observed under a compound microscope to estimate the approximate disease composition for each site. Foliar disease estimates were recorded on 10 randomly selected leaves between FGS 11.1 and 11.2 (15 to 28 days after the FGS 10.5.1 application), depending on the site. FHB developed at trace levels at 2 of the 10 sites and glume blotch developed in only 1 year of the study. Therefore, wheat spike disease data were omitted from this analysis.

Plots were harvested with small-plot research combines when grain moisture approached $13.5 \%$. Delaware and Maryland plots

Table 2. Description of fungicide programs evaluated for their effects on foliar diseases and grain yield in soft red winter wheat in Delaware, Maryland, Virginia, and Pennsylvania in 2015 and 2016

\begin{tabular}{|c|c|c|c|c|c|}
\hline Programa & Fungicides $^{\mathbf{b}}$ & Fungicide active ingredients (\% a.i. $)^{\mathrm{c}}$ & Total a.i. $\left(\mathrm{g} \mathrm{ha}^{-1}\right)^{\mathrm{d}}$ & Timing (FGS) $)^{\mathrm{e}}$ & $\begin{array}{r}\text { Product rate } \\
\left(\text { liter ha } \mathbf{h a}^{-1}\right)^{\mathrm{f}}\end{array}$ \\
\hline$\overline{\mathrm{CK}}$ & $\ldots$ & Nontreated control & $\ldots$ & $\cdots$ & \\
\hline TSOLO8 & Tilt & Propiconazole $41.8 \%$ & 126 & 8 & 0.29 \\
\hline TSPLT5+8 & Tilt FB Tilt & Propiconazole $41.8 \%$ & 63,126 & $5+8$ & $0.15,0.29$ \\
\hline TSPLT5+F & Tilt FB Prosaro & $\begin{array}{l}\text { Propiconazole } 41.8 \% \text { FB prothioconazole } \\
19 \% \text { and tebuconazole } 19 \%\end{array}$ & $63,100,100$ & $5+10.5 .1$ & $0.15,0.48$ \\
\hline QSOLO8 & Quilt Xcel & $\begin{array}{l}\text { Azoxystrobin } 13.5 \% \text { and propiconazole } \\
11.7 \%\end{array}$ & 94,108 & 8 & 0.77 \\
\hline QSPLT5+8 & Quilt Xcel FB Quilt Xcel & $\begin{array}{l}\text { Azoxystrobin } 13.5 \% \text { and propiconazole } \\
11.7 \%\end{array}$ & $63,72,94,108$ & $5+8$ & $0.51,0.77$ \\
\hline QSPLT5+F' & Quilt Xcel FB Prosaro & $\begin{array}{l}\text { Azoxystrobin } 13.5 \% \text { and propiconazole } \\
11.7 \% \text { FB prothioconazole } 19 \% \text { and } \\
\text { tebuconazole } 19 \%\end{array}$ & $63,72,100,100$ & $5+10.5 .1$ & $0.51,0.48$ \\
\hline XSOLO8 & Priaxor & $\begin{array}{l}\text { Fluxapyroxad } 14.33 \% \text { and pyraclostrobin } \\
28.58 \%\end{array}$ & 97,49 & 8 & 0.29 \\
\hline XSPLT5+8 & Priaxor FB Prixaor & $\begin{array}{l}\text { Fluxapyroxad } 14.33 \% \text { and pyraclostrobin } \\
28.58 \%\end{array}$ & $49,24,97,49$ & $5+8$ & $0.15,0.29$ \\
\hline XSPLT5+Fg & Priaxor FB Prosaro & $\begin{array}{l}\text { Fluxapyroxad } 14.33 \% \text { and pyraclostrobin } \\
28.58 \% \text { FB prothioconazole } 19 \% \text { and } \\
\text { tebuconazole } 19 \%\end{array}$ & $49,24,100,100$ & $5+10.5 .1$ & $0.15,0.48$ \\
\hline SSOLO8 & Stratego YLD & $\begin{array}{l}\text { Prothioconazole } 10.8 \% \text { and trifloxystrobin } \\
32.3 \%\end{array}$ & 37,110 & 8 & 0.29 \\
\hline SSPLT5+8 & Stratego YLD FB Stratego YLD & $\begin{array}{l}\text { Prothioconazole } 10.8 \% \text { and trifloxystrobin } \\
32.3 \%\end{array}$ & $18,55,37,110$ & $5+8$ & $0.15,0.29$ \\
\hline SSPLT5+F & Stratego YLD FB Prosaro & $\begin{array}{l}\text { Prothioconazole } 10.8 \% \text { and trifloxystrobin } \\
32.3 \% \text { FB Prothioconazole } 19 \% \text { and } \\
\text { tebuconazole } 19 \%\end{array}$ & $18,55,100,100$ & $5+10.5 .1$ & $0.15,0.48$ \\
\hline PSOLOFg & Prosaro & Prothioconazole $19 \%$ and tebuconazole $19 \%$ & 100,100 & 10.5 .1 & 0.48 \\
\hline $\begin{array}{l}\text { a Program cod } \\
\text { b Fungicides v } \\
{ }^{c} \text { Tilt formulat } \\
\text { centrates (SC } \\
\text { d Total a.i. list } \\
\text { e FGS = Feek }\end{array}$ & $\begin{array}{l}\text { to be used in following sections y } \\
\text { ith FB = followed by indicate a sec } \\
\text { d as emulsifiable concentrate (EC) } \\
\text { d in order of product as presented } \\
\text { growth stage. }\end{array}$ & $\begin{array}{l}\text { en describing fungicide programs. } \\
\text { ential application. } \\
\text { Quilt Xcel as suspo-emulsion (SE); and Pria } \\
\text { the fungicides column. }\end{array}$ & atego YLD, and & o formulated & spension con- \\
\hline
\end{tabular}


were harvested with a Massey Ferguson 8XP research plot combine (Kincaid Equipment Manufacturing, Haven, KS) equipped with a Harvest Master HM400 or HM800 GrainGage (Juniper Systems, Inc., Logan, UT) coupled to a field computer (Allegro CX and Mirus; Juniper Systems, Inc.) that immediately measured grain yield (bushels per acre) and moisture. Virginia plots were harvested with a Wintersteiger Elite plot combine (Wintersteiger, Salt Lake City, UT), bagged, and later weighed on an Ohaus DS10 scale (Ohaus, Parsippany, NJ), and moisture was measured on a Dickey John GAC 2000 (Dickey-John, Auburn, IL). Pennsylvania plots were harvested with a Wintersteiger Nurserymaster Elite, bagged, and later weighed on an Adam CPWplus compact scale (Adam Equipment, Inc, Oxford, CT), and grain moisture was measured with a John Deere SW08120 moisture tester (Deere \& Company, Moline, IL). Yield data were adjusted to $13.5 \%$ moisture and converted to kilograms per hectare based on a bushel weight of $25.87 \mathrm{~kg} / \mathrm{bushel}\left(\mathrm{kg} \mathrm{bu}^{-1}\right)$, which is less than the industry standard of $27 \mathrm{~kg} \mathrm{bu}^{-1}$ but more representative of SRWW grown in the region based on 87 site-years of regional variety performance trials (data not presented).

Effect of fungicide program on yield. Following Willyerd et al. (2015), PROC MIXED was used to determine the effects of fungicide program on yield. Each environment and response was analyzed separately by fitting a linear mixed model with fixed effect of fungicide program and block as a random effect. The lsmeans statement in MIXED was used to estimate the expected least square mean yield for each program. The estimated values were then used in a multitreatment random-effects meta-analysis across all studies in order to estimate the overall mean yield difference between fungicide program and the control $(\bar{D})$, along with their $95 \%$ confidence interval and the between-study variance $\left(\hat{\sigma}^{2}\right)$. The metaanalytical model was fitted to the data in PROC MIXED of SAS using maximum likelihood as the parameter estimation method, as described previously (Paul and Madden 2015; Paul et al. 2011). The model was expanded to include a bivariated moderator of disease severity class on the yield effect, which classified the studies based on the foliar severity in the nontreated check as high (above or equal to 15\%; five trials) and low (below 15\%; five trials) (Madden et al. 2016).

Fungicide program effect on the risk of foliar disease on the flag leaf. Significant contributions to yield come from the flag leaf but foliar diseases may compromise the health of the flag leaf, especially late in the season during grain fill. Foliar fungicides are a management tool used to minimize the impact of these diseases; however, they vary in effectiveness, depending on the product used and application timing. To gain a better understanding of how these fungicide programs performed in terms of disease control, foliar disease severity data (each of the 10 observations from each plot for a total of 7,980 observations across all sites) were compressed into a four-class scale, where category $1=$ no disease on the flag leaf, category $2=1$ to $5 \%$ disease severity on flag leaf, category $3=5$ to $15 \%$ disease severity on the flag leaf, and category $4=$ more than $15 \%$ disease severity on the flag leaf. Following Willyerd et al. (2015), a generalized linear mixed model was used to estimate the odds or likelihood of a fungicide program resulting in a certain level of foliar disease on the flag leaf. The proportional odds model was fitted to the data pooled across the 10 environments using the PROC GLIMMIX procedure in SAS to estimate the odds of disease severity being assigned to one of the four categories previously described, given a fungicide program. Proportional odds models were fitted to the cumulative logit link function $(\eta)$ of foliar disease class, with the distribution as multinomial. The model can be written as:

$$
\begin{aligned}
& \eta_{0 j k m}=\log \left(\frac{\pi_{0 j k m}}{1-\pi_{0 j k m}}\right)=\theta_{0}+\beta_{j}+\varphi_{m}+b(\varphi)_{k m} \\
& \eta_{1 j k m}=\log \left(\frac{\pi_{0 j k m}+\pi_{1 j k m}}{1-\left(\pi_{0 j k m}+\pi_{1 j k m}\right)}\right)=\theta_{1}+\beta_{j}+\varphi_{m}+b(\varphi)_{k m}
\end{aligned}
$$

$$
\eta_{2 j k m}=\log \left(\frac{\pi_{0 j k m}+\pi_{1 j k m}+\pi_{2 j k m}}{1-\left(\pi_{0 j k m}+\pi_{1 j k m}+\pi_{2 j k m}\right)}\right)=\theta_{2}+\beta_{j}+\varphi_{m}+b(\varphi)_{k m}
$$

where $\log (\bullet)$ is the natural $\log$ link function, $\pi_{\bullet j k m}$ is the probability of disease severity falling into a certain severity category (reaching or exceeding a certain level of severity on the flag leaf) for the $j$ th treatment in the $k$ th block and $m$ th environment, $\beta_{j}$ is the fixed effect of the $j$ th treatment on $\eta, \varphi_{m}$ is the random effect of the $m$ th environment, $b(\varphi)_{k m}$ is the random effect of the $k$ th block within the $m$ th environment, and $\theta_{\bullet}$ is an intercept term for each equation (the transition between the classes). The probability of severity class 0 (disease restricted to below the flag leaf) is $\pi_{0 j k m} ; \pi_{1 j k m}$ is the probability of disease reaching the flag leaf but below $5 \%$ severity; $\pi_{2 j k m}$ is the probability of disease on the flag leaf between 5 to $15 \%$ severity; and the probability of disease on the flag above $15 \%$ severity, $\pi_{3 j k m}$, was estimated as $1-\pi_{0 j k m}-\pi_{1 j k m}-\pi_{2 j k m}$. The estimate statement in GLIMMIX was then used along with the ilink option to estimate probability values (Willyerd et al. 2015).

Projected yield response to different fungicide programs. The potential for fungicide programs to increase yield under certain conditions has been well documented. However, growers are also interested in their return on investment; mainly, what is the likelihood of a specific fungicide program being profitable and which ones are the most likely to be profitable. The estimated expected effect size and estimated between-study variance for each fungicide program $\left(\bar{D}\right.$ and $\hat{\sigma}_{D}^{2}$, respectively) from the meta-analysis were used to estimate the probability of yield responses in new, randomly selected studies (done in a manner similar to the studies in this investigation) being above some critical level $(D c)$ needed to offset application cost at a given grain price (Willyerd et al. 2015). As a way of assessing the cost-benefit of the fungicide programs evaluated in this study, probabilities were estimated for each program for a range of $D c$ as $\rho=\varnothing\left(\left(\bar{D}-D_{c}\right) / \hat{\sigma}_{D}\right)$ (Willyerd et al. 2015), where $\varnothing(\bullet)$ is the cumulative standard-normal function and $\hat{\sigma}_{D}$ is the estimated between-study standard deviation for the difference $\left(\sqrt{\hat{\sigma}_{D}^{2}}\right)$. Probabilities were estimated for grain prices of $\$ 0.11 \mathrm{~kg}^{-1}(\$ 3.00$ $\left.\mathrm{bu}^{-1}\right), \$ 0.18 \mathrm{~kg}^{-1}\left(\$ 5.00 \mathrm{bu}^{-1}\right)$, and $\$ 0.26 \mathrm{~kg}^{-1}\left(\$ 7.00 \mathrm{bu}^{-1}\right)$, representing low, average, and high prices, respectively, in each year; fungicide and application costs were obtained by surveying five agribusiness retailers and custom applicators representing the region. The cost of one ground application was applied to each program, including two-pass programs, because the cost of application would have been already accounted for, given that most growers normally apply liquid nitrogen fertilizer at FGS 5 (Salgado et al. 2017; Willyerd et al. 2015).

\section{Results}

Fungicide program effect on yield. Across all fungicide programs, mean yield was greatest at sites FT15 $\left(5,947 \mathrm{~kg} \mathrm{ha}^{-1}\right)$ and PA16 $\left(5,699 \mathrm{~kg} \mathrm{ha}^{-1}\right)$ and lowest at FT16 $\left(3,829 \mathrm{~kg} \mathrm{ha}^{-1}\right)$ and VA16 (4,037 $\left.\mathrm{kg} \mathrm{ha}^{-1}\right)$ (Supplementary Fig. S1A). Minimum, mean, and maximum grain yield across all 10 environments were 2,508, 4,973, and 7,211 $\mathrm{kg} \mathrm{ha}^{-1}$, respectively (Supplementary Fig. S2). The overall mean effect size $(\bar{D})$ was significantly different from zero $(P \leq 0.01)$ for all fungicide programs (Table 3 ). Program overall mean effect size $(\bar{D})$ ranged from 254 to $634 \mathrm{~kg} \mathrm{ha}^{-1}$, with a mean $(\bar{D})$ of $446 \mathrm{~kg} \mathrm{ha}^{-1}$. For the effect of program timing on grain yield, the overall mean effect size $(\bar{D})$ was significantly different $(P \leq 0.01)$ from zero for all timing comparisons, except FGS 8 versus FGS 10.5.1 and FGS 10.5.1 versus FGS 5 followed by (FB) FGS 8, which were not significant ( $P \geq 0.838$ and $P \geq 0.11$, respectively). FGS 5 FB FGS 10.5.1 resulted in a mean effect size $(\bar{D})$ that was $183 \mathrm{~kg} \mathrm{ha}^{-1}$ greater than FGS 8, $171 \mathrm{~kg} \mathrm{ha}^{-1}$ greater than FGS 10.5.1, and $94 \mathrm{~kg} \mathrm{ha}^{-1}$ greater than FGS 5 FB FGS 8. FGS 5 FB FGS 8 resulted in a mean effect size $(\bar{D})$ that was $88 \mathrm{~kg} \mathrm{ha}^{-1}$ greater than FGS 8 . The yield was not significantly affected by the disease severity class $(P \geq 0.60)$, regardless of the program used. 
Fungicide program effect on the risk of foliar disease on the flag leaf. Only diseases of the LBC were detected on the flag leaf in 2015. In 2016, LBC was the most commonly encountered foliar disease on the flag leaf and, across sites, averaged $74 \%$ of the total disease on the flag leaf, followed by leaf rust $(21 \%)$, powdery mildew $(4 \%)$, and stripe rust $(<1 \%)$. Across all treatments, mean percent flag leaf area infected between FGS 11.1 and 11.2 varied across sites and years and was greatest at FT16 (47.4\%), GT16 (23\%), and HB16 $(10 \%)$ and lowest at WY15 (0.4\%), FT15 (1.1\%), and GT15 $(1.3 \%)$. Minimum, mean, and maximum disease severity on the flag leaf across all 10 environments were $<1,10$, and $99 \%$, respectively (Supplementary Fig. S3). Over 60\% of the 7,980 total individual observations (individual flag leaves) were grouped in either category 1 (no foliar disease on the flag leaf; Fig. 1A) or category 2 (1 to 5\% disease severity on the flag leaf; Fig. 1B). Nontreated checks had the greatest probability $(0.65)$ of falling into category $4(\geq 15 \%$ disease severity on the flag leaf; Fig. 1D).

Fungicide programs that included a fungicide application at FGS 10.5.1 resulted in the greatest probability $(0.29$ to 0.40$)$ of disease not reaching the flag leaf compared with all other programs, which had $\leq 0.11$ probability (Fig. 1A). The probability of foliar disease reaching the flag leaf and resulting in 1 to $5 \%$ severity ranged from 0.38 to 0.66 across all programs (Fig. 1B). Slight differences existed between products though, on average, no one program provided a significant increase or decrease in probabilities based on timings. Fungicide programs including an FGS 10.5.1 application, in general, had lower probabilities $(0.05$ to 0.09$)$ of foliar disease reaching 5 to $15 \%$ on the flag leaf compared with programs with an application at FGS 8 (0.24 to 0.52) (Fig. 1C). Fungicide programs including an application at FGS 5 FB FGS 8 or FGS 10.5.1 applications did not substantially increase or reduce the chances of foliar disease reaching the flag leaf or exceeding a certain level on the flag leaf. For example, TSOLO8 had a 0.49 probability of severity being in category 3, whereas the corresponding probability for TSPLT5+8 was 0.45 . The probability of $\geq 15 \%$ disease severity on the flag leaf was low $(<0.07)$ for all programs.

Projected yield response to different fungicide programs. All of the fungicide programs had a more than 0.60 probability of resulting in a yield increase in a new random study, given conditions similar to those observed in this study (Figs. 2A, 3A, and 4A). For all programs, probability decreased as the projected yield response increased from 0 to $1,500 \mathrm{~kg} \mathrm{ha}^{-1}$. For example, the fungicide program QSOLO8 had a 0.64 probability of a yield increase of $7.5 \mathrm{~kg} \mathrm{ha}^{-1}$ but only a 0.11 probability of $1,500 \mathrm{~kg} \mathrm{ha}^{-1}$. The probability of obtaining a yield increase high enough to offset fungicide application costs (breakeven) decreased as application costs increased and increased as grain price increased from $\$ 0.11 \mathrm{~kg}^{-1}\left(\$ 3.00 \mathrm{bu}^{-1}\right)$ to $0.26 \mathrm{~kg}^{-1}$ $\left(\$ 7.00 \mathrm{bu}^{-1}\right.$ ) (Figs. 2B, C, and D; 3B, C, and D; and 4B, C, and D;). Using the fungicide price data we collected from local agribusinesses, the probability of profitability for programs was similar for all programs with an application at FGS 8, ranging from 0.49 to 0.56 , compared with a single application at FGS 10.5.1 timing (0.53) using a wheat price of $\$ 0.18 \mathrm{~kg}^{-1}$ (Fig. 2C). Programs with an applications at FGS 5 FB FGS 8 did not increase the probability of profitability, on average, when compared with single applications at FGS 8 (Fig. 3C). For example, the probability increased from 0.54 to 0.57 for TSOLO 8 and TSPLT5+8 and 0.54 to 0.55 for QSOLO 8 and QSPLT5+8 but decreased from 0.49 to 0.48 for XSOLO8 and XSPLT $5+8$ and from 0.56 to 0.52 for SSOLO 8 and SSPLT5+8 (Fig. 3C). Programs with an application at FGS 5 FB FGS 10.5.1 did increase the chance of profitability compared with single applications at FGS 10.5.1; however, this increase was small, only amounting to a $1 \%$ increase at $\$ 0.11 \mathrm{~kg}^{-1}, 3 \%$ at $\$ 0.18 \mathrm{~kg}^{-1}$, and $5 \%$ at $\$ 0.26 \mathrm{~kg}^{-1}$ grain prices (Fig. 4B to D).

\section{Discussion}

This is the first study to use meta-analysis to describe the potential profitability of multiple fungicides and fungicide timings in SRWW grown in the mid-Atlantic states of Delaware, Maryland, Pennsylvania, and Virginia. This work adds to previous research conducted in the Midwest (Willyerd et al. 2015) and mid-Atlantic (Weisz et al. 2011), by assessing a wider range of fungicide programs for potential profitability and foliar disease control. Fungicide applications at FGS 10.5.1 are becoming increasingly popular for foliar disease control in mid-Atlantic SRWW. Recent threats from FHB have elevated grower awareness of management practices, which include planting a moderately resistant variety and applying FHB-specific fungicides at FGS 10.5.1 if risk levels are high (Willyerd et al. 2012). Using a multivariate random-effects meta-analysis, Paul et al. (2008) reported that the triazole fungicides Prosaro, Caramba, and Proline had the greatest efficacy against FHB when applied at anthesis (FGS 10.5.1), and a subsequent study showed that these fungicides were just as effective against FHB when applied within 6 days after the start of FGS 10.5.1 (D'Angelo et al. 2014). Our data indicate that Prosaro applied at FGS 10.5.1 can provide just as good control of foliar diseases

Table 3. Mean difference (effect size) and corresponding statistics from random-effects meta-analysis of the effect of fungicide programs on grain yield in soft red winter wheat from field experiments conducted in Delaware, Maryland, Virginia, and Pennsylvania in 2015 and 2016

\begin{tabular}{lrrrrc}
\hline Contrast $^{\mathbf{b}}$ & $\overline{\boldsymbol{D}}$ & $\mathbf{s e}(\overline{\boldsymbol{D}})$ & \multicolumn{1}{c}{$\boldsymbol{P}$} & \multicolumn{1}{c}{$\boldsymbol{C I}_{\boldsymbol{L}}$} & $\boldsymbol{C I}_{\boldsymbol{U}}$ \\
\hline TSOLO8 versus CK & 253.65 & 104.85 & 0.016 & 48.12 & 459.19 \\
TSPLT5+8 versus CK & 331.51 & 96.26 & $<0.001$ & 142.83 & 520.20 \\
TSPLT5+F versus CK & 520.54 & 100.92 & $<0.001$ & 322.73 & 718.36 \\
QSOLO8 versus CK & 405.03 & 112.66 & $<0.001$ & 184.20 & 625.86 \\
QSPLT5+8 versus CK & 569.53 & 154.43 & $<0.001$ & 266.81 & 872.25 \\
QSPLT5+F versus CK & 634.16 & 143.34 & $<0.001$ & 353.18 & 915.14 \\
SSOLO8 versus CK & 329.49 & 98.92 & $<0.001$ & 135.58 & 523.39 \\
SSPLT5+8 versus CK & 419.85 & 103.49 & $<0.001$ & 217.00 & 622.70 \\
SSPLT5+F versus CK & 482.42 & 129.66 & $<0.001$ & 228.26 & 736.57 \\
XSOLO8 versus CK & 460.19 & 107.74 & $<0.001$ & 248.99 & 671.38 \\
XSPLT5+8 versus CK & 481.21 & 100.46 & $<0.001$ & 284.29 & 678.13 \\
XSPLT5+F versus CK & 542.40 & 122.99 & $<0.001$ & 301.32 & 783.49 \\
PSOLOF versus CK & 373.69 & 111.82 & $<0.001$ & 154.49 & 592.89 \\
FGS8 versus FGS5 & -88.44 & 36.35 & 0.015 & -159.70 & -17.18 \\
FB FGS8c & & & & & \\
FGS8 versus FGS5 & -182.79 & 38.47 & $<0.001$ & -258.20 & -107.38 \\
FB FGS10.5.1 & & & & & \\
FGS8 versus FGS10.5.1 & -11.60 & 56.64 & 0.838 & -122.63 & 99.42 \\
FGS10.51 versus FGS5 & -76.84 & 48.01 & 0.110 & -170.95 & 17.28 \\
FB FGS8 & & & & & \\
FGS10.51 versus FGS5 & -171.19 & 52.40 & 0.001 & -273.91 & -68.47 \\
FB FGS10.5.1 & & & & & \\
FGS5 FB FGS8 versus & -94.36 & 32.83 & 0.004 & -158.70 & -30.01 \\
FGS5 FB FGS10.5.1 & & & & & \\
\hline
\end{tabular}

$\overline{\mathrm{D}}=$ effect size as mean grain yield difference for each fungicide program relative to the nontreated check and for comparisons between selected pairs of application timings, averages across programs (below the broken line); se $(\bar{D})=$ standard error of $\bar{D}$; lower $\left(\mathrm{CI}_{\mathrm{L}}\right)$ and upper $\left(\mathrm{CI}_{\mathrm{U}}\right)$ limits of the $95 \%$ confidence interval (CI) around $\bar{D}$; and $P=$ probability value (significance level) for the effect of treatment on yield.

${ }^{\mathrm{b}}$ Fungicide programs included nontreated control (CK), Tilt (41\% propiconazole) applied at full rate (0.29 liter ha $\left.{ }^{-1}\right)$ at Feekes growth stage (FGS) 8 (TSOLO8), Tilt applied at half rate at FGS 5 followed by (FB) full rate at FGS 8 (TSPLT5+8) or Prosaro (19\% prothioconazole $+19 \%$ tebuconazole) applied at full rate (0.48 liter ha $\left.{ }^{-1}\right)$ at FGS 10.5.1 (TSPLT5+F), Quilt Xcel $(13.5 \%$ azoxystrobin $+11.7 \%$ propiconazole) applied at full rate $(0.77$ liter $\mathrm{ha}^{-1}$ ) at FGS 8 (QSOLO8), Quilt Xcel applied at reduced rate at FGS 5 FB full rate at FGS 8 (QSPLT5+8) or Prosaro applied at full rate at FGS 10.5.1 (QSPLT5+F), Stratego YLD (10.8\% prothioconazole $+32.3 \%$ trifloxystrobin) applied at full rate (0.29 liter ha $\left.{ }^{-1}\right)$ at FGS 8 (SSOLO8), Stratego YLD applied at half rate at FGS 5 FB full rate at FGS 8 (SSPLT5+8) or Prosaro applied at full rate at FGS 10.5.1 (SSPLT5+F), Priaxor $(14.33 \%$ fluxapyroxad $+28.58 \%$ pyraclostrobin) applied at full rate (0.29 liter $\mathrm{ha}^{-1}$ ) at FGS 8 (XSOLO8), Priaxor applied at half rate at FGS 5 FB full rate at FGS 8 (XSPLT5+8) or Prosaro applied at full rate at FGS 10.5.1 (XSPLT5 $+\mathrm{F})$, and Prosaro applied at full rate at FGS 10.5.1 (PSOLOF).

${ }^{\mathrm{c}}$ Individual programs were collapsed into their respective timings: FGS 8 includes TSOLO8, QSOLO8, SSOLO8, and XSOLO8; FGS5 FB FGS8 includes TSPLT5+8, QSPLT5+8, SSPLT5+8, and XSPLT5+8; FGS5 FB FGS10.5.1 includes TSPLT5+F, QSPLT5+F, SSPLT5+F, and XSPLT5+F; and FGS 10.5.1 includes PSOLOF. 
compared with programs with an application at FGS 8. The observed results were due to the fact that foliar disease did not develop until after anthesis (FGS 10.5.1).

Although several foliar diseases were encountered in this study, LBC was the most frequently observed disease complex across all environments. Diseases causing LBC are residue borne and require prolonged periods of leaf wetness and temperatures warmer than those typical of the pre-FGS 8 period to produce spores and infect the leaves (Bergstrom 2010; McMullen 2010; Shaner 2010). Thus, environmental conditions in the region typically are not favorable for the development of this disease complex until after FGS 8, when canopies have closed and, therefore, can hold moisture for extended periods of time (Kleczewski 2014b, 2017a,b). This, coupled with relatively slow spore production times that result in new infections, may explain the similar effectiveness between FGS 8 and FGS 10.5.1 fungicide applications observed in this study. Development of LBC prior to FGS 8 would require persistent, wet conditions and moderate temperatures, which occur infrequently in the region during early wheat development stages in March and April. Our results are consistent with field observations and single-season fungicide efficacy trials conducted in the region in recent years (Kleczewski 2014a,d, 2017a,b). Subtle differences between fungicide programs with FGS 8 and FGS 10.5.1 applications on flag leaf disease severity did not result in a significant difference in yield response between the two timings when compared with the nontreated check. For example, PSOLOF had a yield response of $374 \mathrm{~kg} \mathrm{ha}^{-1}$, which was greater than SSOLO8 (329 $\left.\mathrm{kg} \mathrm{ha}^{-1}\right)$ and TSOLO8 $\left(254 \mathrm{~kg} \mathrm{ha}^{-1}\right)$ but not QSOLO8 $\left(405 \mathrm{~kg} \mathrm{ha}^{-1}\right)$ or XSOLO8 $\left(460 \mathrm{~kg} \mathrm{ha}^{-1}\right)$. Using fungicide price data provided by local agribusinesses, our results indicated that both FGS 10.5.1 and FGS 8 applications resulted in similar probability of profitability. Thus, our data indicate that Prosaro applied at FGS 10.5.1 did not result in reduced grain yield response or likelihood of profitability compared with fungicide programs with an application at FGS 8.

The use of the FGS 10.5.1 application may provide additional economic benefits that were beyond the scope of our objectives.

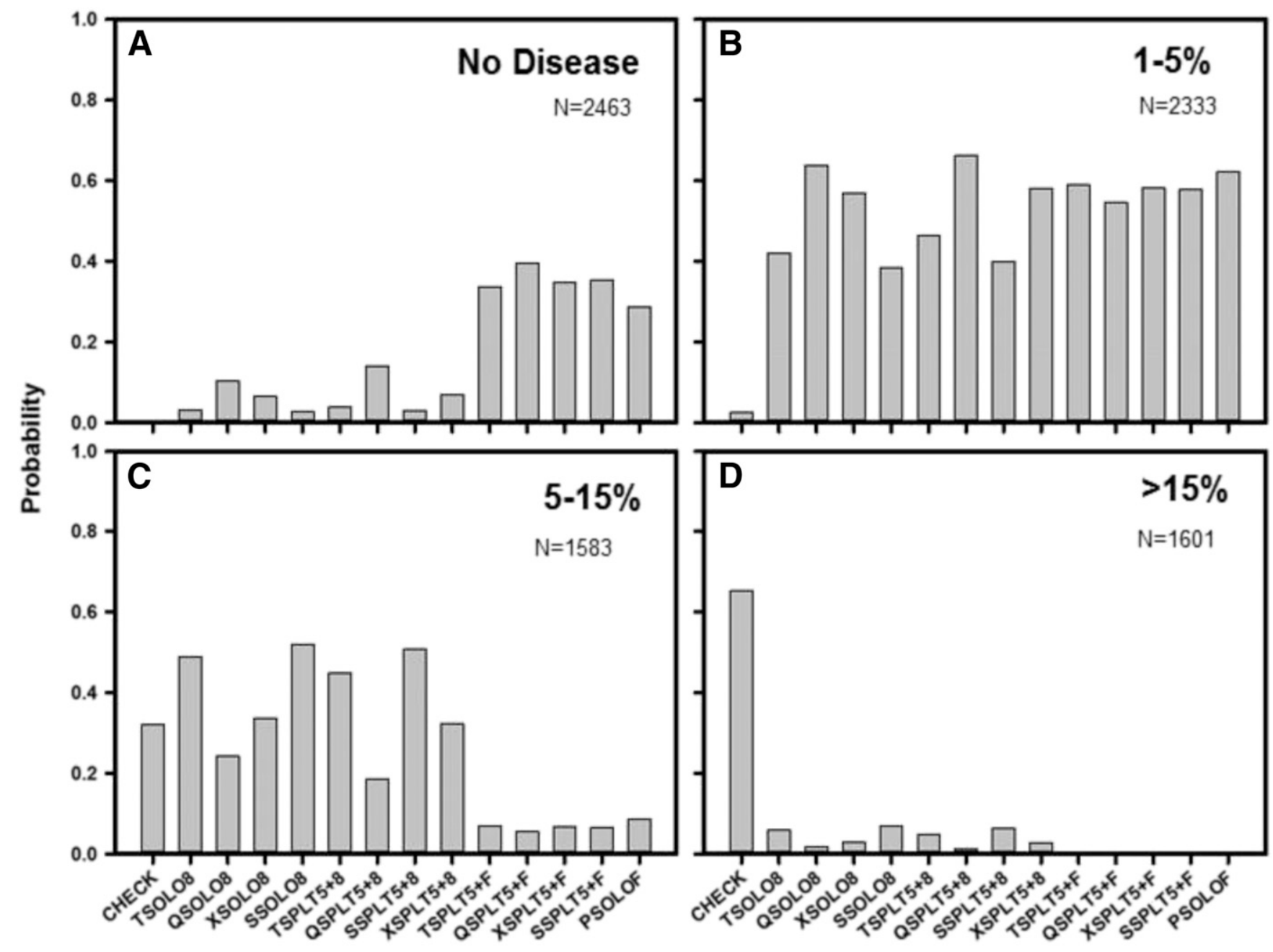

Treatments

Fig. 1. Probability of wheat foliar disease severity reaching one of four new categories, which include $\mathbf{A}$, category 1 : no foliar disease on the flag leaf; $B$, category $2: 1$ to $5 \%$ disease severity on the flag leaf; C, category 3:5 to15\% disease severity on the flag leaf; and D, category $4:>15 \%$ disease severity on the flag leaf according to assessments taken between Feekes growth stage (FGS) 11.1 and 11.2. Estimates were based on individual observations from field experiments conducted in four mid-Atlantic states from 2015 to 2016 and entered into a generalized linear mixed model to generate the likelihood of disease severity being placed in a one of the four categories given a fungicide program. Fungicide programs included Tilt (41\% propiconazole) applied at full rate $\left(0.29\right.$ liter ha $\left.{ }^{-1}\right)$ at FGS 8 (TSOLO8), Tilt applied at half rate at FGS 5 followed by (FB) full rate at FGS 8 $($ TSPLT5 +8$)$ or Prosaro $\left(19 \%\right.$ prothioconazole $+19 \%$ tebuconazole) applied at full rate $\left(0.48\right.$ liter ha $\left.{ }^{-1}\right)$ at FGS $10.5 .1($ TSPLT5+F), Quilt Xcel $(13.5 \%$ azoxystrobin + $11.7 \%$ propiconazole) applied at full rate $\left(0.77\right.$ liter $\left.\mathrm{ha}^{-1}\right)$ at FGS 8 (QSOLO8), Quilt Xcel applied at reduced rate at FGS 5 FB full rate at FGS 8 (QSPLT5+8) or Prosaro applied at full rate at FGS 10.5 .1 (QSPLT5+F), Stratego YLD $\left(10.8 \%\right.$ prothioconazole $+32.3 \%$ trifloxystrobin) applied at full rate $\left(0.29\right.$ liter ha $\left.{ }^{-1}\right)$ at $F G S 8$ (SSOL08), Stratego YLD applied at half rate at FGS 5 FB full rate at FGS 8 (SSPLT5+8) or Prosaro applied at full rate at FGS 10.5.1 (SSPLT5+F), Priaxor (14.33\% fluxapyroxad $+28.58 \%$ pyraclostrobin) applied at full rate $\left(0.29\right.$ liter ha $\left.^{-1}\right)$ at FGS 8 (XSOLO8), Priaxor applied at half rate at FGS 5 FB full rate at FGS 8 (XSPLT5+8) or Prosaro applied at full rate at FGS 10.5.1 (XSPLT5+F), and Prosaro applied at full rate at FGS 10.5.1 (PSOLOF). 
Diseases affecting the spike such as glume blotch and FHB can reduce grain quality, resulting in dockage (Cowger et al. 2016b). The use of the FGS 10.5.1 program has been reported to provide significantly better glume blotch control compared with the FGS 8 timing in mid-Atlantic SRRW (Sylvester and Kleczewski 2018). Locally, in 2017 , grain with a test weight below $746 \mathrm{~kg} / \mathrm{mg}^{3}$ was subject to dockage that decreased grain prices by 1 to $11 \%$ as test weight decreased to $682 \mathrm{~kg} / \mathrm{mg}^{3}$, at which point loads of grain were subject to rejection. In addition, mycotoxins such as deoxynivalenol (DON) produced by $F$. graminearum can result in dockage or rejection of the grain if concentrations of the toxin exceed 2 ppm (Cowger et al. 2016b; Ransom and McMullen 2008). It has been suggested that the United States reduce the allowable concentration of DON in wheat destined for human consumption to match Brazilian and European standards of 1.25 ppm (Belluco et al. 2017; Pinotti et al. 2016), placing additional importance on minimizing mycotoxin contamination of SRWW grain. Research conducted across multiple states and years in the Midwest reported that Prosaro applied at or within 6 days after FGS 10.5.1 was the most effective timing to suppress FHB and resulting DON concentrations (D'Angelo et al. 2014). In a 2-year study conducted in Ohio, Salgado et al. (2014) reported that this timing, when integrated with additional management strategies such as host resistance and modifications to harvesting equipment, reduced
DON by 32 to $50 \%$, resulting in reduced price discounts and an economic benefit of $\$ 31$ to $272 \mathrm{ha}^{-1}$. However, the same management strategies without Prosaro at FGS 10.5.1 only reduced DON concentrations by 4.3 to $38.7 \%$. Furthermore, test weight and DON concentrations directly dictate marketing options and whether grain can be sold to the potentially more lucrative flour mill market for human consumption or on the often less-profitable animal feed market (Cowger et al. 2016b). Coupled with effective spike disease management and mycotoxin management, applications made at FGS 10.5.1 are also effective against late-season diseases such as rusts (Salgado et al. 2017). Although we did encounter leaf rust in our study, it does not overwinter in the region and, therefore, disease development is dependent on the arrival of spores from warmer, southern regions. This, coupled with relatively high-temperature optima (Kolmer 2010), often results in leaf rust developing in the canopy late in the growing season. Recently, the region has suffered from outbreaks of stripe rust (Puccinia striiformis) which, similar to the leaf rust pathogen, enters the region from warmer, southern areas. However, unlike leaf rust, stripe rust epidemics can develop rapidly under cool, wet conditions often encountered during earlier phases of crop growth in the mid-Atlantic. Fortunately, variety selection and regional disease monitoring can be used to effectively determine the need for a fungicide application during a particular growing season.
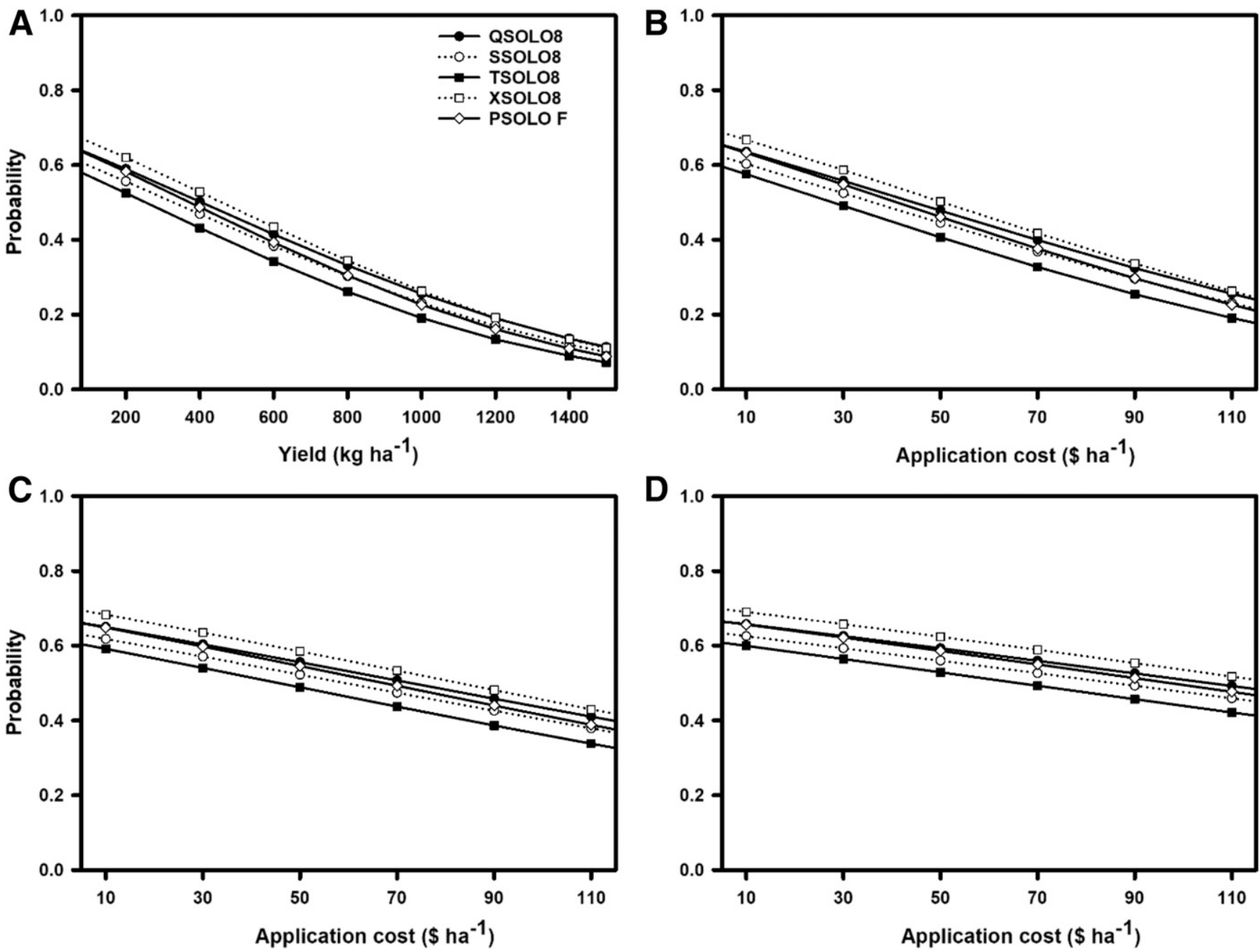

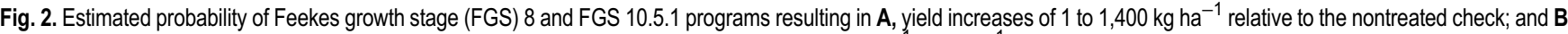
to D, profitability of break-even at grain prices of $\$ 0.11(\$ 3.00), \$ 0.18(\$ 5.00)$, and $\$ 0.26(\$ 7.00) \mathrm{kg}^{-1}$ (bushel ${ }^{-1}$ ), respectively, for a range of application costs. Estimates were based on mean effect sizes and between-study variances from a random-effects meta-analysis from field experiments conducted in the mid-Atlantic states from 2015 to 2016 to evaluate the effects of fungicides programs for foliar disease control on wheat grain yield. Fungicide programs included Tilt $(41 \%$ propiconazole $)$ applied at full rate $\left(0.29\right.$ liter ha $\left.{ }^{-1}\right)$ at FGS 8 (TSOLO8), Quilt Xcel (13.5\% azoxystrobin + 11.7\% propiconazole) applied at full rate (0.77 liter ha ${ }^{-1}$ ) at FGS 8 (QSOLO8), Stratego YLD (10.8\% prothioconazole + $32.3 \%$ trifloxystrobin) applied at full rate $\left(0.29\right.$ liter ha $\left.^{-1}\right)$ at FGS 8 (SSOLO8), Priaxor (14.33\% fluxapyroxad $+28.58 \%$ pyraclostrobin) applied at full rate $\left(0.29\right.$ liter ha $\left.{ }^{-1}\right)$ at FGS 8 (XSOLO8), and Prosaro applied at full rate (0.48 liter ha $\left.{ }^{-1}\right)$ at FGS 10.5.1 (PSOLOF). 
The additional advantages associated with the FGS 10.5.1 timing would likely make it a more profitable decision when compared with the FGS 8 timing.

Our data indicate that the use of two-pass programs provides little to no benefit in relation to disease suppression or profitability under the conditions of this study. Programs with an FGS 5 application followed by either FGS 8 or FGS 10.5.1 applications improved yield somewhat when compared with FGS 8 or FGS 10.5.1 singlefungicide programs. Programs with an early application at FGS 5 FB FGS 8 or FGS 10.5.1 applications may have provided some suppression of disease in the lower canopy, though this would not have been captured in the flag leaf severity ratings. A less diseased lower canopy (leaves below the flag) may have resulted in slightly greater yield, which would support the notion that these tissues only supply approximately 5\% of photosynthates for grain fill (Lupton 1972). Indeed, our data indicate an average yield increase of $3 \%$ when comparing two-pass programs to their solo FGS 8 or FGS 10.5.1 counterpart programs. However, the additional cost associated with the extra fungicide application prevented any sizeable increases in the probability of profitability regardless of price scenario. These data support Willyerd et al. (2015), who also reported no significant benefit combining FGS 5 and FGS 8 or FGS 10 applications in the
Great Lakes Region. In addition to the lack of economic benefit with the FGS 5 timing, resistance issues are of concern, given the limited number of fungicide modes of action for use in wheat. Recently, there has been an increase in the number of premix fungicides containing multiple fungicide modes of action. This is problematic, because only fungicides belonging to the DMI class are currently suggested for application to the grain spike given that products with a QoI mode of action have the potential to increase DON in grain (Madden et al. 2014). Examples of DMI resistance in the United States have been recently described in $F$. graminearum (Spolti et al. 2014), and reduced DMI sensitivity in Parastagonospora nodorum has been observed in Europe and China (Pereira et al. 2017). Furthermore, several examples of rusts and powdery mildew developing resistance to DMI fungicides have been documented in other pathosystems (Colcol et al. 2012; Keinath 2015; Lebeda et al. 2010; Schmitz et al. 2014). Consequently, it is important that concepts of integrated disease management be emphasized to wheat producers and the agronomic industry in order to reduce fungicide inputs and increase profitability through effective fungicide application.

In this study, we assessed the effectiveness and profitability of numerous fungicide programs across multiple states in the mid-Atlantic
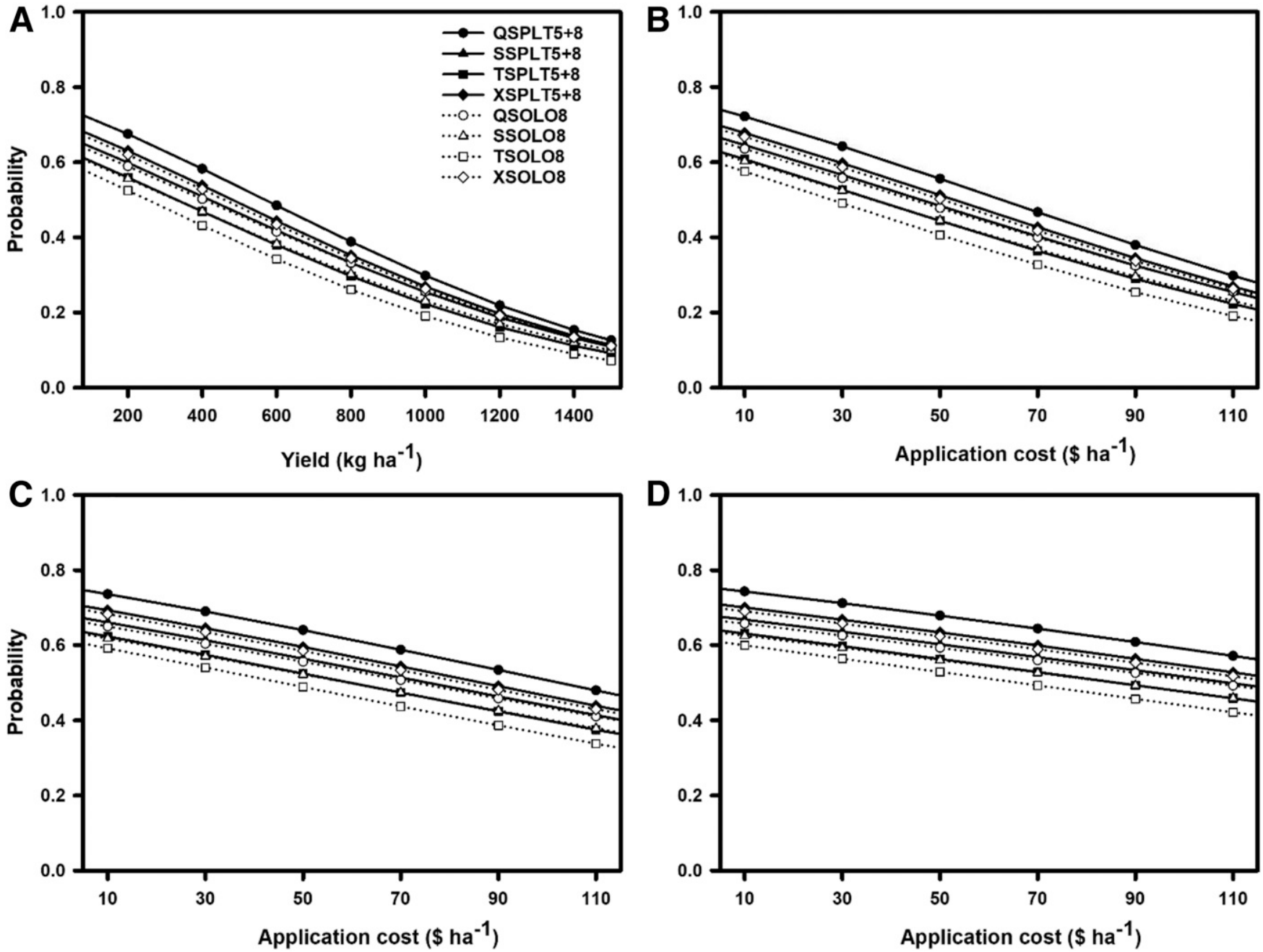

Fig. 3. Estimated probability of Feekes growth stage (FGS) 8 and FGS 5 followed by (FB) FGS 8 programs resulting in A, yield increases of 1 to $1,400 \mathrm{~kg}$ ha ${ }^{-1}$ relative to the nontreated check; and B to D, profitability of break-even at grain prices of $\$ 0.11(\$ 3.00), \$ 0.18(\$ 5.00)$, and $\$ 0.26(\$ 7.00) \mathrm{kg}^{-1}$ (bushel ${ }^{-1}$ ), respectively, for a range of application costs. Estimates were based on mean effect sizes and between-study variances from a random-effects meta-analysis from field experiments conducted in the mid-Atlantic states from 2015 to 2016 to evaluate the effects of fungicides programs for foliar disease control on wheat grain yield. Fungicide programs included Tilt (41\% propiconazole) applied at full rate $\left(0.29\right.$ liter ha $^{-1}$ ) at FGS 8 (TSOLO8), Tilt applied at half rate at FGS 5 followed by (FB) full rate at FGS 8 (TSPLT5+8), Quilt Xcel (13.5\% azoxystrobin + 11.7\% propiconazole) applied at full rate $\left(0.77\right.$ liter ha $\left.{ }^{-1}\right)$ at FGS 8 (QSOLO8), Quilt Xcel applied at reduced rate at FGS 5 FB full rate at FGS 8 (QSPLT5+8), Stratego YLD (10.8\% prothioconazole + $32.3 \%$ trifloxystrobin) applied at full rate $\left(0.29\right.$ liter ha ${ }^{-1}$ ) at FGS 8 (SSOLO8), Stratego YLD applied at half rate at FGS 5 FB full rate at FGS 8 (SSPLT5+8), Priaxor (14.33\% fluxapyroxad $+28.58 \%$ pyraclostrobin) applied at full rate $\left(0.29\right.$ liter ha $\left.{ }^{-1}\right)$ at FGS 8 (XSOLO8), and Priaxor applied at half rate at FGS 5 FB full rate at FGS 8 (XSPLT5+8). 
region over a 2-year period. Although we realize that the results are limited to the conditions encountered in this specific study, we believe that our data provide an excellent representation of the average or likely fungicide response in this region and other regions because our findings are consistent with those reported elsewhere (Weisz et al. 2011; Willyerd et al. 2015). Environmental conditions varied widely during the course of this study, ranging from hot and dry for the region (mean temperature and rainfall of $18.3^{\circ} \mathrm{C}$ and $20 \mathrm{~cm}$, respectively) to wet and cool (mean temperature and rainfall of $16.8^{\circ} \mathrm{C}$ and $35 \mathrm{~cm}$, respectively). The 5-year average temperature and rainfall for this time period are $17.6^{\circ} \mathrm{C}$ and $29.5 \mathrm{~cm}$, respectively (Legates et al. 2005; NOAA 2017; University of Maryland 2017; Virginia Tech 1997). Thus, our findings, although limited in terms of the number of site years, represents a wide spectrum of environmental, epidemiological, and production conditions. However, growers and crop consultants are often interested in using disease level as a threshold for decision making. Our results revealed no significant effect of disease severity levels ( $\geq 15 \%$ versus $\leq 15 \%$ severity) on yield response (data not presented). The relatively small data set and the late epidemic progress, generally after flowering, may have contributed to the lack of significance in our study. Future studies may help to clarify the effect of disease level on yield response and subsequent profitability.

We utilized a high-yield-producing variety adapted for the region, which contained average resistance to LBC, leaf rust, and powdery mildew (Kleczewski 2013, 2014b). Therefore, the disease and yield responses reported herein represent a realistic, average response to fungicides in the region. Our research supports that of Weisz et al. (2011), where the probability of a fungicide program resulting in breakeven or net profit can exceed 0.50 when foliar disease is present. However, we recognize that growth-stage-based fungicide applications should not be solely relied upon for managing fungal diseases of the foliage and spike. Significant economic losses can be avoided by implementing an integrated disease management program targeting diseases through selecting resistant varieties, scouting fields to assess disease pressure, and using disease tracking or forecasting tools. Based on our results, we suggest single fungicide applications at either FGS 8 or FGS 10.5.1, rather than two-pass programs with applications at FGS 5 FB FGS 8 or FGS 10.5.1, for managing common foliar diseases in mid-Atlantic SRWW, though crop advisors and growers should also take into account disease pressure, number of years in wheat, previous crop, grain price, and fungicide
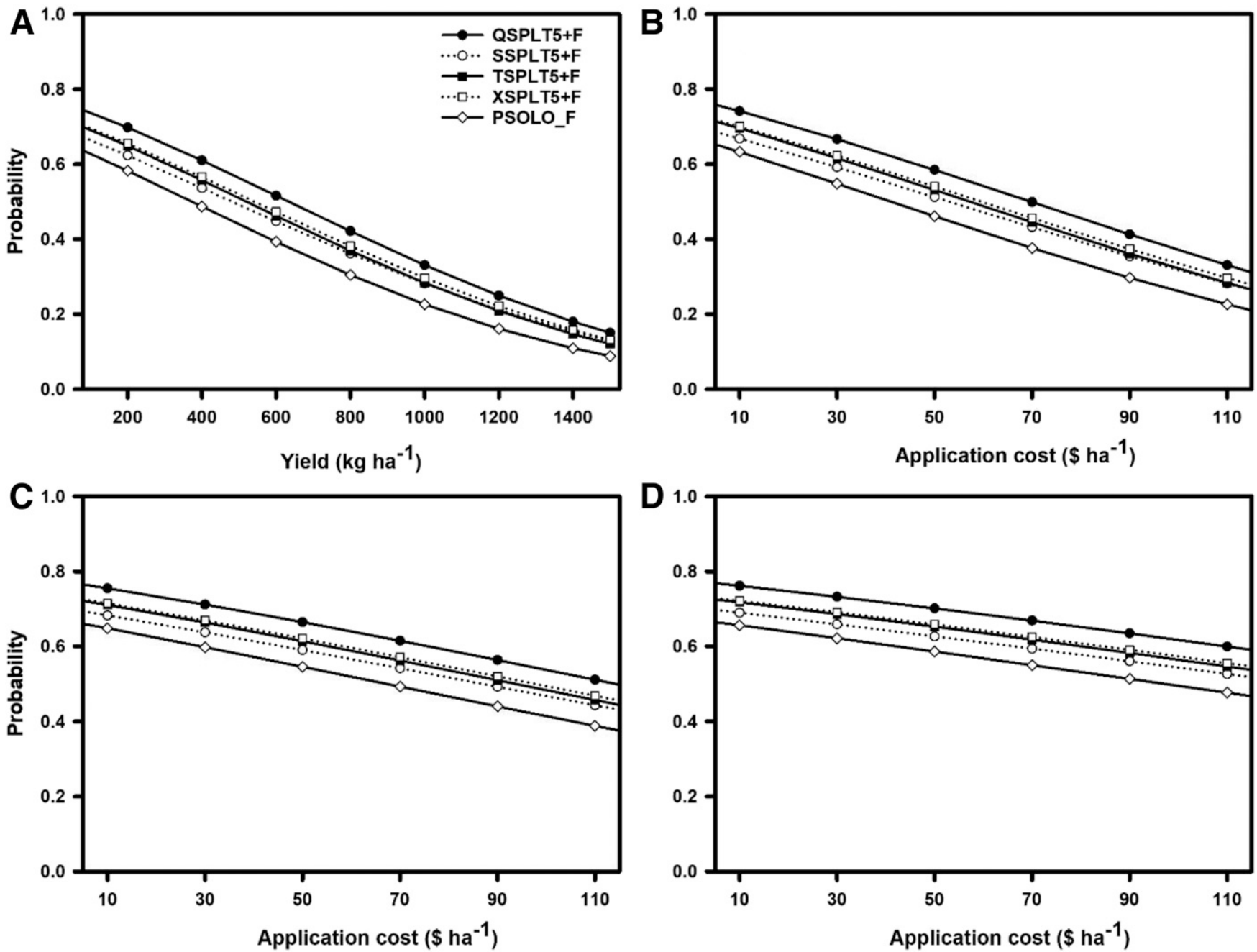

Fig. 4. Estimated probability of Feekes growth stage (FGS) 10.5 .1 and FGS 5 followed by (FB) FGS 10.5 .1 programs resulting in $\mathbf{A}$, yield increases of 1 to 1,400 kg ha ${ }^{-1}$ relative to the nontreated check; and B to D, profitability of break-even at grain prices of $\$ 0.11(\$ 3.00), \$ 0.18(\$ 5.00)$, and $\$ 0.26(\$ 7.00) \mathrm{kg}^{-1}$ (bushel ${ }^{-1}$ ), respectively, for a range of application costs. Estimates were based on mean effect sizes and between-study variances from a random-effects meta-analysis from field experiments conducted in the mid-Atlantic states from 2015 to 2016 to evaluate the effects of fungicides programs for foliar disease control on wheat grain yield. Fungicide programs included Tilt (41\% propiconazole) applied at half rate $\left(0.15\right.$ liter ha $\left.^{-1}\right)$ at FGS 5 followed by (FB) Prosaro (19\% prothioconazole $+19 \%$ tebuconazole) applied at full rate $\left(0.48\right.$ liter ha $\left.{ }^{-1}\right)$ at FGS 10.5 .1 (TSPLT5+F), Quilt Xcel $\left(13.5 \%\right.$ azoxystrobin $+11.7 \%$ propiconazole) applied at reduced rate $\left(0.51\right.$ liter ha $\left.^{-1}\right)$ at FGS 5 FB Prosaro applied at full rate at FGS 10.5 .1 (QSPLT5+F), Stratego YLD $(10.8 \%$ prothioconazole $+32.3 \%$ trifloxystrobin) applied at half rate $\left(0.15\right.$ liter ha $\left.^{-1}\right)$ at FGS 5 FB Prosaro applied at full rate at FGS 10.5.1 (SSPLT5+F), Priaxor (14.33\% fluxapyroxad + 28.58\% pyraclostrobin) applied at half rate $\left(0.15\right.$ liter ha $\left.^{-1}\right)$ at FGS 5 FB Prosaro applied at full rate at FGS 10.5 .1 (XSPLT5+F), and Prosaro applied at full rate at FGS 10.5.1 (PSOLOF). 
cost before making a fungicide application decision. The frameworks presented in this study and that of Willyerd et al. (2015) provide powerful and useful starting points for the development of larger-scale studies involving multiple wheat growing environments, varieties, and classes. Data from such studies could be used to develop tools for use by wheat producers that enable profitability and informed fungicide use.

\section{Acknowledgments}

We thank B. Hearn, V. Green, D. Mitchell, and W. Harris for establishment, maintenance, and harvest of research plots at the University of Delaware Thurman G. Adams Agricultural Research Farm; J. Adkins and W. Willey for establishment and maintenance of research plots at the University of Delaware Warrington Irrigation Research Farm; J. Streett, J. Draper, Jr., and L. Thorne for establishment, maintenance, and harvest of research plots at the University of Maryland Wye Research and Education Center; N. Smith, C. Ramage, and D. Seifrit for help with data collection; and members of the Mehl and Collins programs for their assistance with establishment, maintenance, data collection, and harvest of research plots in Virginia and Pennsylvania.

\section{Literature Cited}

Belluco, B., de Camargo, A. C., da Gloria, E. M., Dias, C. T. S., Button, D. C., and Calori-Domingues, M. A. 2017. Deoxynivalenol in wheat milling fractions: A critical evaluation regarding ongoing and new legislation limits. J. Cereal Sci. 77:284-290.

Bergstrom, G. C. 2010. Stagonospora nodorum blotch and Stagonospora avenae blotch. Pages 75-77 in: Compendium of Wheat Diseases and Pests, Vol. 3. W. W. Bockus, R. L. Bowden, R. M. Hunger, W. L. Morrill, T. D. Murray, and R. W. Smiley, eds. American Phytopathological Society, St. Paul, MN.

Bowen, K. L., Everts, K. L., and Leath, S. 1991. Reduction in yield of winter wheat in North Carolina due to powdery mildew and leaf rust. Phytopathology 81:503-511.

Chen, G. H., Hinds, J., Zobel, E., Rosario-Lebron, A., and Hooks, C. R. R. 2015. Evaluation of prophylactic sprays on pest abundance, foliar damage and yield in winter wheat. Int. J. Pest Manage. 61:161-170.

Coale, F. J. 2010. University of Maryland Extension Soil Fertility ManagementAgronomic Crop Nutrient Recommendations Base on Soil Tests and Yield Goals. Online publication. University of Maryland Extension. https:// extension.umd.edu/anmp/nutrient-recommendations

Colcol, J. F., Rallos, L. E., and Baudoin, A. B. 2012. Sensitivity of Erysiphe necator to demethylation inhibitor fungicides in Virginia. Plant Dis. 96: 111-116.

Cowger, C., Parks, R., and Kosman, E. 2016a. Structure and migration in U.S. Blumeria graminis f. sp. tritici populations. Phytopathology 106:295-304.

Cowger, C., Weisz, R., Arellano, C., and Murphy, P. 2016b. Profitability of integrated management of Fusarium head blight in North Carolina winter wheat. Phytopathology 106:814-823.

Curran, W., Johnson, Q., VanGessel, M., Schulz, B., Cahoon, C., Flessner, M., and Chandran, R. 2016. 2016 Mid-Atlantic Field Crop Weed Management Guide. Online publication. Penn State; University of Delaware; University of Maryland; Virginia Tech; West Virginia University. https://extension.psu. edu/publications/agrs-136

D’Angelo, D. L., Bradley, C. A., Ames, K. A., Willyerd, K. T., Madden, L. V., and Paul, P. A. 2014. Efficacy of fungicide applications during and after anthesis against Fusarium head blight and deoxynivalenol in soft red winter wheat. Plant Dis. 98:1387-1397.

Ficke, A., Cowger, C., Bergstrom, G. C., and Brodal, G. 2018. Understanding yield loss and pathogen biology to improve disease management: Septoria nodorum blotch-a case study in wheat. Plant Dis. 102:696-707.

Green, A. J., Berger, G., Griffey, C. A., Pitman, R., Thomason, W., and Balota, M. 2014. Genetic resistance to and effect of leaf rust and powdery mildew on yield and its components in 50 soft red winter wheat cultivars. Crop Prot. 64: $177-186$.

Herbert, A., and Flessner, M. 2016. Pest Management Guide, Field Crops, 2016. Online publication. Virginia Cooperative Extension. https://pubs.ext.vt.edu/ 456/456-016/456-016.html

Keinath, A. P. 2015. Efficacy of fungicides against powdery mildew on watermelon caused by Podosphaera xanthii. Crop Prot. 75:70-76.

Kleczewski, N. 2013. 2013 Wheat Variety Trial Disease Report. Online publication. University of Delaware Cooperative Extension. http://extension.udel. edu/ag/field-crop-resources/variety-trials-corn-hybrids-small-grains-soybeans/

Kleczewski, N. 2014a. Effect of foliar fungicides and timings on powdery mildew and tan spot in Maryland, 2014. Plant Dis. Manage. Rep. 9:CF012

Kleczewski, N. 2014b. 2014 Wheat Variety Trial Disease Writeup. Online publication. University of Delaware. http://extension.udel.edu/ag/field-cropresources/variety-trials-corn-hybrids-small-grains-soybeans/

Kleczewski, N. 2014c. Effect of Prosaro and F. graminearum application timing on Fusarium head blight in Delaware, 2014. Plant Dis. Manage. Rep. 9:CF011.

Kleczewski, N. 2014d. Effect of foliar fungicides, growth regulator, and timings on powdery mildew and tan spot in Maryland, 2014. Plant Dis. Manage. Rep. 9. $\mathrm{CF} 023$
Kleczewski, N. 2017a. Effect of foliar fungicides and timings on leaf blotch complex on wheat in Maryland, 2016. Plant Dis. Manage. Rep. 11:CF021.

Kleczewski, N. 2017b. Effect of foliar fungicides and timings on leaf blotch complex on wheat in Delaware, 2016. Plant Dis. Manage. Rep. 11:CF020.

Kolmer, J. A. 2010. Leaf rust. Page 53 in: Compendium of Wheat Diseases and Pests, Vol. 3. W. W. Bockus, R. L. Bowden, R. M. Hunger, W. L. Morrill, T. D. Murray, and R. W. Smiley, eds. American Phytopathological Society, St. Paul, MN.

Large, E. C. 1954. Growth stages in cereals-Illustration of the Feekes scale. Plant Pathol. 3:128-129.

Lebeda, A., McGrath, M. T., and Sedláková, B. 2010. Fungicide resistance in cucurbit powdery mildew fungi. Pages 221-246 in: Fungicides. O. Carisse, ed. InTechOpen. https://www.intechopen.com/books/fungicides/fungicideresistance-in-cucurbit-powdery-mildew-fungi.

Legates, D. R., Leathers, D. J., DeLiberty, T. L., Quelch, G. E., Brinson, K., Butke, J., Mahmood, R., and Foster, S. A. 2005. DEOS: The Delaware Environmental Observing System. Proceedings of the 21st International Conference on Interactive Information Processing Systems (IIPS) for Meteorology, Oceanography, and Hydrology, 8-14 January 2005, American Meteorology Society, San Diego, CA (CD-ROM).

Lopez, J. A., Rojas, K., and Swart, J. 2015. The economics of foliar fungicide applications in winter wheat in Northeast Texas. Crop Prot. 67:35-42.

Lupton, F. G. H. 1972. Further experiments on photosynthesis and translocation in wheat. Ann. Appl. Biol. 71:69-79.

Madden, L., Bradley, C., Dalla Lana, F., and Paul, P. A. 2014. Meta-analysis of 19 years of fungicide trials for the control of Fusarium head blight of wheat. Pages 17-18 in: Proc. 2014 Natl. Head Blight Forum. S. Canty, A. Clark, N. Turcott, and D. Van Sanford, eds. U.S. Wheat \& Barley Scab Initiative, St. Louis.

Madden, L. V., Piepho, H.-P., and Paul, P. A. 2016. Statistical models and methods for network meta-analysis. Phytopathology 106:792-806.

Maguire, R. O., and Heckendorn, S. E. 2015. Soil Test Recommendations for Virginia. Online publication. Virginia Cooperative Extension. https://www. soiltest.vt.edu/content/dam/soiltest_vt_edu/PDF/recommendation-guidebook.pdf

McMullen, M. 2010. Tan spot (yellow leaf spot). Pages 82-84 in: Compendium of Wheat Diseases and Pests, Vol. 3. W. W. Bockus, R. L. Bowden, R. M. Hunger, W. L. Morrill, T. D. Murray, and R. W. Smiley, eds. American Phytopathological Society, St. Paul, MN.

Milus, E. A., and Chalkley, D. B. 1997. Effect of previous crop, seedborne inoculum, and fungicides on development of Stagonospora blotch. Plant Dis. $81: 1279-1283$

NOAA. 2017. National Centers for Environmental Information. Online publication. National Oceanic and Atmospheric Administration. Station GHCND USC00364778-LANDISVILLE 2 NW, PA US. https://www.ncdc.noaa.gov/ cdo-web/search

Paul, P., and Madden, L. 2015. Meta-analysis in plant disease epidemiology. Pages 137-145 in: Exercises in Plant Disease Epidemiology. K. L. Stevenson and M. J. Jeger, eds. American Phytopathological Society, St. Paul, MN.

Paul, P. A., Lipps, P. E., Hershman, D. E., McMullen, M. P., Draper, M. A., and Madden, L. V. 2008. Efficacy of triazole-based fungicides for Fusarium head blight and deoxynivalenol control in wheat: A multivariate meta-analysis. Phytopathology 98:999-1011.

Paul, P. A., Madden, L. V., Bradley, C. A., Robertson, A. E., Munkvold, G. P., Shaner, G., Wise, K. A., Malvick, D. K., Allen, T. W., Grybauskas, A., Vincelli, P., and Esker, P. 2011. Meta-analysis of yield response of hybrid field corn to foliar fungicides in the U.S. corn belt. Phytopathology 101: 1122-1132.

Pereira, D. A. S., McDonald, B. A., and Brunner, P. C. 2017. Mutations in the CYP51 gene reduce DMI sensitivity in Parastagonospora nodorum populations in Europe and China. Pest Manage. Sci. 73:1503-1510.

Phipps, P., Rideout, S. L., and Thomason, W. 2012. Evaluation of fungicides in wheat for foliar disease control and impact on yield, 2012. Plant Dis Manage. Rep. 7:CF001.

Pinotti, L., Ottoboni, M., Giromini, C., Dell'Orto, V., and Cheli, F. 2016 Mycotoxin contamination in the EU feed supply chain: A focus on cereal byproducts. Toxins (Basel) 8:45.

Ransom, J. K., and McMullen, M. V. 2008. Yield and disease control on hard winter wheat cultivars with foliar fungicides. Agron. J. 100:1130-1137.

Roth, G. W., Curran, W., and Lingenfelter, D. 2016. The Penn State Agronomy Guide 2015-2016. Online publication. Pennsylvania State University Extension. https://extension.psu.edu/publications/agrs-026

Salgado, J. D., Lindsey, L., and Paul, P. A. 2017. Effects of row spacing and nitrogen rate on wheat grain yield and profitability as influenced by diseases. Plant Dis. 101:1998-2011.

Salgado, J. D., Madden, L. V., and Paul, P. A. 2014. Efficacy and economics of integrating in-field and harvesting strategies to manage Fusarium head blight of wheat. Plant Dis. 98:1407-1421.

Salgado, J. D., Madden, L. V., and Paul, P. A. 2015. Quantifying the effects of Fusarium head blight on grain yield and test weight in soft red winter wheat. Phytopathology 105:295-306.

Schmitz, H. K., Medeiros, C. A., Craig, I. R., and Stammler, G. 2014. Sensitivity of Phakopsora pachyrhizi towards quinone-outside-inhibitors and demethylationinhibitors, and corresponding resistance mechanisms. Pest Manage. Sci. 70 $378-388$ 
Shaner, G. 2010. Septoria tritici blotch. Pages 56-58 in: Compendium of Wheat Diseases and Pests, Vol. 3. W. W. Bockus, R. L. Bowden, R. M. Hunger, W. L. Morrill, T. D. Murray, and R. W. Smiley, eds. American Phytopathological Society, St. Paul, MN.

Shober, A. L., Taylor, R. W., Gartley, K. L., and Sims, J. T. 2017. University of Delaware Nutrient Management Recommendations-Agronomic Crops, Wheat. University of Delaware Cooperative Extension, Newark. http://extension.udel. edu/factsheets/agronomic-crops/

Spolti, P., Del Ponte, E. M., Dong, Y. H., Cummings, J. A., and Bergstrom, G. C. 2014. Sensitivity in a contemporary population of Fusarium graminearum from New York wheat and competitiveness of a tebuconazole-resistant isolate. Plant Dis. 98:607-613.

Sylvester, P. N., and Kleczewski, N. M. 2018. Evaluation of foliar fungicide programs in Mid-Atlantic winter wheat production systems. Crop Prot. 103:103-110.

Thompson, N. M., Epplin, F. M., Edwards, J. T., and Hunger, R. M. 2014. Economics of foliar fungicides for hard red winter wheat in the USA southern Great Plains. Crop Prot. 59:1-6.

University of Delaware. 2012-2014. Variety Trials-Corn, Small Grains and Soybeans. Online publication. University of Delaware, College of Agriculture and Natural Resources. http://extension.udel.edu/ag/field-crop-resources/varietytrials-corn-hybrids-small-grains-soybeans/

University of Maryland. 2012-2014. University of Maryland Wheat and Barley Trials. J. K. Costa and R. A. Cooper, ed. University of Maryland. https://psla. umd.edu/extension/extension-project-pages/small-grains-maryland

University of Maryland. 2017. Weather Data. Online publication. University of Maryland, College of Agriculture and Natural Resources, Wye Research and Education Center. http://agresearch.umd.edu/wye/weather-data

USDA-NASS. 2016. 2016 Small Grains Summary. Online publication. United States Department of Agriculture-National Agricultural Statistics Service, Washington, DC. http://usda.mannlib.cornell.edu/MannUsda/viewDocumentInfo.do?documentID= 1268

USDA-NASS. 2017a. 2016 Summary of Crop Values. Online publication. United States Department of Agriculture-National Agricultural Statistics
Service, Washington, DC. http://usda.mannlib.cornell.edu/MannUsda/ viewDocumentInfo.do?documentID $=1050$

USDA-NASS. 2017b. Flour Milling Products-2016 Summary. Online publication. United States Department of Agriculture-National Agricultural Statistics Service, Washington, DC. http://usda.mannlib.cornell.edu/usda/current/FlourMillAnn/ FlourMillAnn-05-01-2017.pdf

Virginia Tech. 1997. Peanut-Cotton InfoNet. Online publication. Virginia Cooperative Extension, Virginia Tech. Tidewater Agric. Res. Ext. Cent. Inf. Ser. No. 377. http://webipm.ento.vt.edu/cgi-bin/infonet1.cgi

Wegulo, S. N., Stevens, J., Zwingman, M. V., and Baenziger, P. S. 2012. Yield response to foliar fungicide application in winter wheat. Pages 227-244 in: Fungicides for Plant and Animal Diseases. D. Dhanasekaran, ed. InTechOpen. https://www.intechopen.com/books/fungicides-for-plantand-animal-diseases/yield-response-to-foliar-fungicide-application-inwinter-wheat.

Wegulo, S. N., Zwingman, M. V., Breathnach, J. A., and Baenziger, P. S. 2011 Economic returns from fungicide application to control foliar fungal diseases in winter wheat. Crop Prot. 30:685-692.

Weisz, R., Cowger, C., Ambrose, G., and Gardner, A. 2011. Multiple MidAtlantic field experiments show no economic benefit to fungicide application when fungal disease is absent in winter wheat. Phytopathology 101:323-333.

Willyerd, K. T., Bradley, C. A., Chapara, V., Conley, S. P., Esker, P. D., Madden, L. V., Wise, K. A., and Paul, P. A. 2015. Revisiting fungicide-based management guidelines for leaf blotch diseases in soft red winter wheat. Plant Dis. 99:1434-1444.

Willyerd, K. T., Li, C., Madden, L. V., Bradley, C. A., Bergstrom, G. C., Sweets, L. E., McMullen, M., Ransom, J. K., Grybauskas, A., Osborne, L., Wegulo, S. N., Hershman, D. E., Wise, K., Bockus, W. W., Groth, D., Dill-Macky, R., Milus, E., Esker, P. D., Waxman, K. D., Adee, E. A., Ebelhar, S. E., Young, B. G., and Paul, P. A. 2012. Efficacy and stability of integrating fungicide and cultivar resistance to manage Fusarium head blight and deoxynivalenol in wheat. Plant Dis. 96:957-967. 